\title{
O Ensino Religioso não confessional na Base Nacional Comum Curricular - BNCC
}

\author{
Heiberle Hirsgberg Horácio ${ }^{1}$
}

Resenha do livro: JUNQUEIRA, Sérgio; SILVEIRA, Emerson Sena da. (Organizadores). O Ensino Religioso na BNCC: teoria e prática para o ensino fundamental. Petrópolis, RJ: Editora Vozes, 2020, 215 páginas.

No ano de 2017 foi homologada a Base Nacional Comum Curricular - BNCC que possui o Ensino Religioso com uma das cinco áreas do conhecimento. A Base Nacional Comum Curricular é estruturada em competências gerais, competências específicas, unidades temáticas, objetos de conhecimento e habilidades. Estruturada em uma concepção entendida como "formação por competência", a BNCC estabelece 10 competências que devem ser desenvolvidas, e define competência como a "mobilização de conhecimentos (conceitos e procedimentos), habilidades (práticas, cognitivas e socioemocionais), atitudes e valores para resolver demandas complexas da vida cotidiana, do pleno exercício da cidadania e do mundo do trabalho". (BRASIL, BNCC, 2017).

$\mathrm{Na}$ Área do Conhecimento de Ensino Religioso as unidades temáticas são: a) identidades e alteridades; b) manifestações religiosas; c) crenças religiosas e filosofias de vida. Como não poderia deixar de ser, os objetos de conhecimento e as habilidades a serem desenvolvidas são adequadas às faixas etárias. As finalidades do Ensino Religioso estão presentes nas competências específicas, elas são seis:

1. Conhecer os aspectos estruturantes das diferentes tradições/movimentos religiosos e filosofias de vida, a partir de pressupostos científicos, filosóficos, estéticos e éticos.

2. Compreender, valorizar e respeitar as manifestações religiosas e filosofias de vida, suas experiências e saberes, em diferentes tempos, espaços e territórios.

3. Reconhecer e cuidar de si, do outro, da coletividade e da natureza, enquanto expressão de valor da vida.

\footnotetext{
${ }^{1}$ Pós-Doutor em Ciências Sociais. Professor do Programa de Pós-Graduação em Educação, do Depto de Filosofia e do curso de Ciências da Religião da Universidade Estadual de Montes Claros. Montes Claros, Minas Gerais, Brasil. E-mail: heiberle@ hotmail.com. ORCID: https://orcid.org/0000-0002-4486-1764.
} 
4. Conviver com a diversidade de crenças, pensamentos, convicções, modos de ser e viver.

5. Analisar as relações entre as tradições religiosas e os campos da cultura, da política, da economia, da saúde, da ciência, da tecnologia e do meio ambiente.

6. Debater, problematizar e posicionar-se frente aos discursos e práticas de intolerância, discriminação e violência de cunho religioso, de modo a assegurar os direitos humanos no constante exercício da cidadania e da cultura de paz. (BRASIL, BNCC, 2017).

Após a homologação da BNCC, que trouxe como umas das cinco áreas do conhecimento o Ensino Religioso, foram publicados diferentes artigos e livros que versam sobre esse componente curricular na BNCC, mas, também, sobre as Diretrizes Curriculares Nacionais para o curso de licenciatura em Ciências da Religião - área base do Ensino Religioso - que foram homologadas em 2018, um ano após a homologação da BNCC.

$\mathrm{Na}$ esteira dessas produções sobre a Base Nacional Comum Curricular e o Ensino Religioso, a Editora Vozes, de Petrópolis, lançou em 2020 o livro “O Ensino Religioso na BNCC: teoria e prática para o Ensino Fundamental". O livro foi organizado pelos professores Emerson Sena da Silveira - doutor em Ciência da Religião e professor no

Programa de Pós-Graduação em Ciência da Religião, da Universidade Federal de Juiz de Fora - e Sérgio Rogério Azevedo Junqueira, livre-docente em Ciência da Religião, na PUC-SP, e doutor em Ciência da Educação, pela UPS-Roma.

O livro "O Ensino Religioso na BNCC: teoria e prática para o Ensino Fundamental" é dividido em nove capítulos, e possui o prefácio escrito por Gilberto Garcia, Presidente da Comissão do Ensino Religioso no CNE, e Relator das Diretrizes Curriculares Nacionais das Ciências da Religião no CNE.

Os capítulos são: 1) O Ensino Religioso: uma história em construção, escrito por Lurdes Caron e Lourival José Martins filho; 2) Ciência(s) da Religião: um quadro de referências para o Ensino Religioso, de Emerson Sena da Silveira e Dayana Dar'c e Silva da Silveira; 3) O Ensino Religioso segundo a BNCC, de Sérgio Rogério Azevedo Junqueira, e Sonita de Itoz; 4) Diretrizes do Ensino Religioso na Base Nacional Comum Curricular: aportes teóricos e ideias para a prática docente no Ensino Fundamental, de Elisa Rodrigues; 5) Conhecimento religioso: possibilidades de aprendizagem a partir da BNCC, por Edile Maria Fracaco Rodrigues; 6) Metodologia e didática em face da BNCC, de Cláudia Regina Kluck; 7) Diversidade religiosa e cultural e a Base Nacional Comum 
Curricular, de Marcos Vinicius de Freitas Reis; 8) Identidade e alteridade na BNCC: importância para o Ensino Religioso na perspectiva das Ciências da Religião, por Gilbraz de Souza Aragão; e 9) Crenças religiosas e filosofias de vida na BNCC: importância para o Ensino Religioso sob a perspectiva da Ciência da Religião, de Matheus Oliva da Costa, e Fábio L. Stern.

O livro é leitura fundamental para os graduandos e graduandas em Ciência(s) da Religião, e para as professoras e professores de Ensino Religioso, uma vez que o livro traz valiosas reflexões sobre a BNCC e sobre o trabalho com Ensino Religioso amparado nela, servindo, desse modo, de orientação para que o Ensino Religioso nas escolas seja realizado de maneira não confessional, não proselitista, e que seja reflexivo e sobre as diversas religiões e "filosofias de vida" (BRASIL, BNCC, 2017). Mas o livro é leitura fundamental, também, para todos e todas profissionais da Educação, uma vez que é imprescindível a leitura de um livro que verse sobre temas, questões e debates para o combate à discriminação religiosa, violências, preconceitos e invisibilizações no interior das escolas. 